\title{
Provenance, geochemistry and grain-sizes of glacigene sediments, including the Sirius Group, and Late Cenozoic glacial history of the southern Prince Albert Mountains, Victoria Land, Antarctica
}

\author{
Sandra Passchier, ${ }^{1}$ Anja L.L.M. Verbers, ${ }^{2}$ Frederik M. van der Wateren, ${ }^{3}$ Frans J.M. Vermeulen ${ }^{4}$ \\ ${ }^{1}$ Department of Geological Sciences, Ohio State University, 130 Orton Hall, 155 South Oval Mall, Columbus, OH 43210, U.S.A. \\ ${ }^{2}$ Physical Geography Department, University of Utrecht, Heidelberglaan 2, 3584 CS Utrecht, The Netherlands \\ ${ }^{3}$ Department of Earth Sciences, Free University, De Boelelaan 1085, 1081 HVAmsterdam, The Netherlands \\ ${ }^{4}$ Netherlands Institute of Applied Geoscience TNO/National Geological Survey, Section of Geochemical Mapping, \\ P.O. Box 157, 2000 AD Haarlem, The Netherlands
}

\begin{abstract}
The southern Prince Albert Mountains, between David and Mawson Glaciers $\left(75^{\circ} 30^{\prime}\right.$ to $\left.76^{\circ} \mathrm{S}\right)$ inVictoria Land, Antarctica, comprise a series of nunataks with elevations ranging from $800 \mathrm{~m}$ near the coast to $2300 \mathrm{~m} \sim 130 \mathrm{~km}$ inland. Geochemical and grain-size analyses of tills from these nunataks reveal three major groups of deposits:

(1) coarse to medium sandy tills, found on glacially streamlined summit plateaus of Kirkpatrick Basalt above $2000 \mathrm{~m}$ a.s.l., with geochemical compositions very similar to those of the underlying Jurassic Kirkpatrick Basalt;

(2) bimodal silty and sandy tills of the Sirius Group with Ferrar/Beacon-dominated geochemical compositions, at elevations of 1300-1600 m a.s.l. on striated summit plateaus and high-elevation terraces;

(3) fine-grained tills with high $\mathrm{SiO}_{2}$ contents from ice-cored moraines at the lee sides of large nunataks.

The geochemical composition of sandy tills from the highest summit plateaus suggests that valleys had not yet cut through the Kirkpatrick Basalt and into Beacon and Ferrar rocks at the time of deposition. These tills represent a phase of temperate glaciation prior to deposition of diatom-bearing Sirius Group tills. The latter were deposited after a first phase of landscape dissection as inferred from geochemical data. The fine-grained icecored moraines are late-Pleistocene basal tills.

The presence of pre-Pliocene glacial deposits on high mountain summits in the Prince Albert Mountains has implications for the interpretation of high-elevation Sirius Group sediments in other areas of the Transantarctic Mountains. It is possible that the "Sirius debate" has its origin in interpretations of both thin, barren pre-Pliocene deposits on high mountain summits and thick sequences of diatom-bearing deposits in valleys elsewhere in the Transantarctic Mountains. Both types of deposits are associated with the Sirius Group, but they belong to separate glacial episodes.
\end{abstract}

\section{INTRODUCTION}

\section{Background}

The current East Antarctic ice cover is a stable, predominantly cold-based terrestrial ice sheet. Tills, glaciofluvial and glaciolacustrine deposits, at many locations in the Transantarctic Mountains suggest that temperate ice-sheet conditions existed during part of the Cenozoic glacial history. The deposits are known as the Sirius Group and are found at high elevations in these mountains (Mercer, 1968, 1972; Webb and others, 1984; Mayewski and Goldthwait, 1985; McKelvey and others, 1991). The discovery of clasts with late-Pliocene marine diatoms in some of these sediments dated them to <3.0 Ma (Webb and others, 1984), which was confirmed by the dating of a volcanic ash deposit $(2.77 \mathrm{Ma})$ occurring in this Pliocene diatom zone in the CIROS 2 drillhole in Ferrar Fjord (Barrett and others,
1992). Webb and others (1984) suggested that the diatombearing sediments were deposited by a temperate ice sheet expanding towards the Transantarctic Mountains after a period of significant deglaciation in the early-mid-Pliocene, when marine transgression into the subglacial Wilkes and Pensacola basins occurred. Proxy data derived from deepsea drilling programs (DSDPs) are compatible with this hypothesis. Oxygen-isotope diagrams of DSDP 846 in the Pacific Ocean (Shackleton and others, 1995) indicate decreasing global ice volumes between 4.5 and $3.5 \mathrm{Ma}$ if the assumption of constant cool deep-ocean temperatures is valid. Oxygen-isotope data from the Atlantic Ocean at DSDP site 607 (Raymo, 1992) show that climate oscillations become progressively "colder" from 3.1 to $2.6 \mathrm{Ma}$ and that the cold extremes between 3.1 and $2.95 \mathrm{Ma}$ still show more negative $\delta^{18} \mathrm{O}$ values than modern values. This means that bottom waters were $3.5^{\circ} \mathrm{C}$ warmer than today and/or that Antarctic ice volumes were significantly smaller. Micro- 
paleontological evidence suggests that the mid-Pliocene ( $\sim 3 \mathrm{Ma})$ global climate was significantly warmer than today. However, there is insufficient evidence from the Southern Hemisphere to determine whether this includes melting of the Antarctic ice sheets during the mid-Pliocene (Crowley, 1996).

The age of the Sirius Group is currently much debated, because of the apparent antiquity of landscapes (mid-Miocene) in the Dry Valleys block of the Transantarctic Mountains (Sugden and others, 1993). Analyses of unconsolidated sediments from the Asgard Range (Marchant and others, 1993b) and the Quatermain Mountains (Marchant and others, 1993a) favor a mid-Miocene overriding episode. Evidence from the Dry Valleys suggests that a cold East Antarctic ice sheet (EAIS) developed around $14 \mathrm{Ma}$ and that cold conditions persisted until today. This is in disagreement with climate interpretations based on the discovery of in situ Nothofagus roots and leaf mats in Sirius deposits of the Beardmore Glacier area (Webb and Harwood, 1993). The sea-level curve confirms the build-up of a large Antarctic ice sheet in the mid-Miocene, but it also shows Pliocene sea levels that are higher than today's (Haq and others, 1987). This study suggests that a pre-Pliocene and a Pliocene glacial episode involved a temperate ice sheet, so that the Sirius Group represents multiple glacial cycles in the southern Prince Albert Mountains.

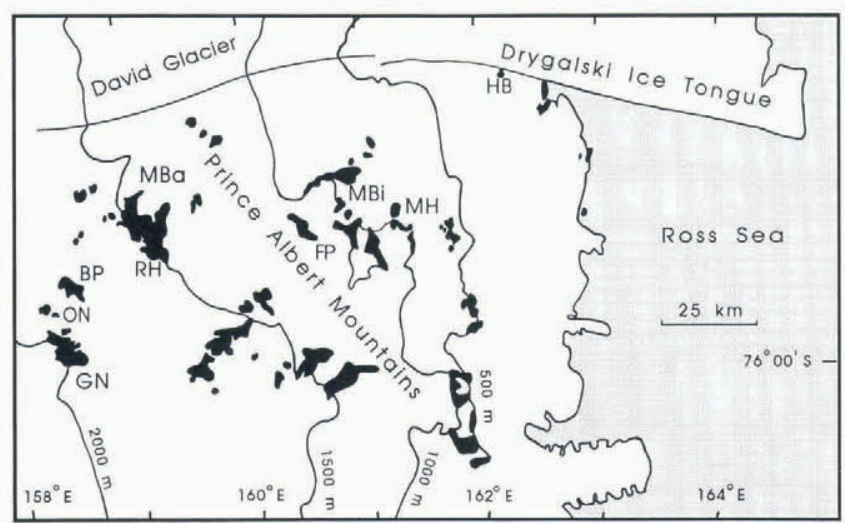

Fig. 1. Map of the southern Prince Albert Mountains. BP, Brimstone Peak; FP, Ford Peak; GN, Griffin Nunatak; HB, Hughes Bluff; MBa, Morris Basin; MBi, Mount Billing; MH, Mount Howard; ON, Outpost Nunatak; RH, Ricker Hills.

\section{Geology and biostratigraphy of the study area}

During GANOVEX expeditions VI and VII in 1991, 1992 and 1993, samples were taken by A.L.L.M. Verbers in the southern Prince Albert Mountains for the purpose of grain-size and geochemical analyses, to determine the provenance of glacial sediments in this region. Samples were taken from flat-topped nunataks rising several hundred meters above the present ice surface, up to elevations of $2340 \mathrm{~m}$ (Fig. 1). The geology of the region is dominated by Devonian Beacon Supergroup sandstones and conglomerates intruded by Jurassic Ferrar Group Sills, and overlain by the Kirkpatrick Basalt of the Ferrar Group. Stacks of lava flows with thicknesses varying from tens to hundreds of meters occur in the highest nunataks most distal from the coast (Wörner, 1992). Near the Ross Sea shore, basement is exposed and consists of Precambrian metamorphic complexes and Ordovician Granite Harbour Intrusives.

The inland nunatak summits $(>2000 \mathrm{~m}$ a.s.l.) are flat plateaus consisting of Kirkpatrick Basalt. The glacially streamlined bedrock (direction southwest-northeast) is covered with discontinuous till blankets of at least $1 \mathrm{~m}$ thickness (Verbers and Van der Wateren, 1992). The coarse fraction of the tills consists of subrounded, and sometimes striated, basalt clasts up to $40 \mathrm{~cm}$ in diameter. The surfaces of the tills are extremely weathered; desert pavement, desert varnish and polygons have developed. Till matrix is reddish brown at Griffin Nunatak.

Glacial terraces and flat mountain summits at lower elevations have thinner till layers with a varying degree of weathering on sometimes striated bedrock. Paleo-ice-flow directions shown by striae from the terraces are southwestnortheast (Verbers and Van derWateren, 1992). Till matrix is brown to gray in color and finer-grained. Clast composition of these tills is mainly Ferrar Group dolerite and Beacon Supergroup sandstone, and occasionally granite. In Cirque Valley (Ricker Hills), glaciofluvial and glaciolacustrine deposits are preserved at elevations of $\sim 1000 \mathrm{~m}$.

A sample from the summit of Mount Billing $(1600 \mathrm{~m})$ contains marine diatoms (Thalassiosira vulnifica and T. lentiginosa) dating from the mid-Pliocene and early Pliocene to Recent. A coarser till from a high terrace at Mount Howard $(1430 \mathrm{~m})$ contains marine diatoms Actinocyclus actinochilus with a first appearance datum (FAD) of $3.1 \mathrm{Ma}$, and $A$. ingens with a range of mid-Miocene to $620 \mathrm{ka}$ (Harwood and Maruyama, 1992; Van der Wateren and others, 1996). A sample from Hughes Bluff $(300 \mathrm{~m})$ contains Thalassiosira vulnifica Gombos, with a range of 3.1-2.2 Ma. The Hughes Bluff deposit occurs at a much lower elevation than the other diatom-bearing tills, and is located at the margin of the valley of the present David Glacier, a large outlet glacier of the EAIS with a valley floor scoured down to $1630 \mathrm{~m}$ below sea level (Swithinbank, 1988; Verbers and Damm, 1994).

Ice-cored moraines are developed on the northeastern side of large nunataks. Clasts in these moraines are mainly derived from the Ferrar Group, but Beacon Supergroup sandstone erratics also occur frequently. A large number of morainic ridges without ice cores at elevations between the present ice surface and the terraces in the study area were also sampled, but will not be discussed in detail. The main focus in this paper will be on a broad transect of glacial deposits in the area between Griffin Nunatak and Hughes Bluff (Fig. 1).

\section{METHOD}

A combination of geochemical and grain-size analyses was used to determine the provenance of the tills. Geochemical analysis of till matrices $(<2 \mathrm{~mm})$ was performed by F.J. M. Vermeulen using XRF and ICP-MS (Vermeulen, 1994). Major elements measured were $\mathrm{SiO}_{2}, \mathrm{TiO}_{2}, \mathrm{Al}_{2} \mathrm{O}_{3}, \mathrm{Fe}_{2} \mathrm{O}_{3}$, $\mathrm{MnO}, \mathrm{MgO}, \mathrm{CaO}, \mathrm{Na}_{2} \mathrm{O}, \mathrm{K}_{2} \mathrm{O}, \mathrm{P}_{2} \mathrm{O}_{5}$; trace elements measured were As, Ba, Cr, Ga, Nb, Ni, Pb, Rb, Sr, Th, V, Y, Zn, Zr.

The sediments are mainly coarse-grained diamicts. For the determination of characteristic grain-sizes the matrices $(<2 \mathrm{~mm})$ of 116 samples were analyzed using a Fritsch laser particle sizer (Analysette 22). Samples were first sieved over $2 \mathrm{~mm}$. Samples were pre-treated by oxidation with $\mathrm{H}_{2} \mathrm{O}_{2}$ to remove organic compounds, and with $\mathrm{HCl}$ to remove inorganic compounds such as $\mathrm{CaCO}_{3}$ and salts. To avoid coagu- 
Table 1. Geochemical composition of Sirius Group till samples from Kirkpatrick Basalt summit plateaus (>2000 m) compared to geochemical data from Kirkpatrick Basalt lava flows. (Main elements in wt \% and trace elements in ppm)

\begin{tabular}{|c|c|c|c|c|c|c|c|}
\hline Sample & $B P$ & $B P$ & $G \mathcal{N}$ & $G \mathcal{N}$ & $O N$ & $A$ & $B$ \\
\hline $\mathrm{SiO}_{2}$ & 56.88 & 56.58 & 57.25 & 56.79 & 55.74 & 56.01 & 56.66 \\
\hline $\mathrm{TiO}_{2}$ & 2.12 & 2.40 & 1.86 & 2.13 & 2.75 & 2.33 & 1.93 \\
\hline $\mathrm{Al}_{2} \mathrm{O}_{3}$ & 11.74 & 11.51 & 11.78 & 11.58 & 10.75 & 11.56 & 12.10 \\
\hline $\mathrm{Fe}_{2} \mathrm{O}_{3}$ & 16.15 & 16.57 & 16.24 & 16.52 & 18.09 & 15.31 & 15.32 \\
\hline $\mathrm{MnO}$ & 0.18 & 0.18 & 1.19 & 0.18 & 0.19 & 0.23 & 0.21 \\
\hline $\mathrm{MgO}$ & 1.25 & 1.39 & 1.13 & 1.20 & 1.23 & 2.12 & 2.30 \\
\hline $\mathrm{CaO}$ & 6.76 & 6.42 & 6.38 & 6.45 & 6.17 & 7.15 & 6.92 \\
\hline $\mathrm{Na}_{2} \mathrm{O}$ & 2.63 & 2.61 & 2.73 & 2.72 & 2.64 & 2.41 & 2.17 \\
\hline $\mathrm{K}_{2} \mathrm{O}$ & 1.81 & 1.86 & 1.93 & 1.91 & 1.92 & 1.77 & 2.14 \\
\hline $\mathrm{P}_{2} \mathrm{O}_{5}$ & 0.30 & 0.29 & 0.33 & 0.32 & 0.33 & 0.26 & 0.27 \\
\hline $\mathrm{Rb}$ & 73 & 72 & 80 & 77 & 77 & 65 & 71 \\
\hline $\mathrm{Sr}$ & 133 & 127 & 143 & 132 & 118 & 128 & 128 \\
\hline V & 449 & 541 & 394 & 440 & 541 & & 391 \\
\hline $\mathrm{Cr}$ & 18 & 26 & 26 & 25 & 28 & & 18 \\
\hline $\mathrm{Ni}$ & 20 & 23 & 17 & 18 & 18 & & 22 \\
\hline $\mathrm{Ba}$ & 552 & 591 & 587 & 597 & 653 & & 398 \\
\hline $\mathrm{Nb}$ & 53 & 52 & 58 & 55 & 56 & & 60 \\
\hline Y & 14 & 16 & 14 & 17 & 18 & & 13 \\
\hline $\mathrm{Zr}$ & 246 & 257 & 263 & 265 & 285 & & 252 \\
\hline Th & 4 & 4 & 8 & 7 & 9 & & 10 \\
\hline
\end{tabular}

Notes: BP, Brimstone Peak; GN, Griffin Nunatak; ON, Outpost Nunatak.

A is flow 12 (top of Kirkpatrick lavas) at Storm Peak, Queen Alexandra Range (Faure and others, 1974).

B is flow at top of Mesa Range lava pile (Siders and Elliot, 1985).

lation of particles in suspension by the presence of positive ions, an excess $800 \mathrm{ml}$ of distilled water was added. After 24 hours the water with the dissolved salts was removed. Peptization was supported by boiling the suspensions with $\mathrm{Na}_{4} \mathrm{P}_{2} \mathrm{O}_{7}$. The Fritsch laser particle sizer determines grainsizes at $0.25 \mathrm{Phi}$ intervals between 0.1 and $1400 \mu \mathrm{m}$ by scanning individual grains. Long-time measurements were made (9000 scans per sample) to get the best result for broad size

Table 2. Geochemical composition of a selection of samples from terraces (Sirius Group), valleys and Pleistocene icecored moraines. (Main elements in wt $\%$ and trace elements in ppm)

\begin{tabular}{|c|c|c|c|c|c|c|c|c|}
\hline Sample & $\begin{array}{c}R H \\
\text { fluvial }\end{array}$ & $\begin{array}{c}R H \\
\text { lacust. }\end{array}$ & $\begin{array}{c}R H \\
\text { valley }\end{array}$ & $\begin{array}{c}M B i \\
\text { summit }\end{array}$ & $\begin{array}{c}\text { MH } \\
\text { summit }\end{array}$ & $\begin{array}{c}\text { MH ter- } \\
\text { race }\end{array}$ & $H B$ & $\begin{array}{l}G N \\
I C M\end{array}$ \\
\hline $\mathrm{SiO}_{2}$ & 76.18 & 69.98 & 74.72 & 65.78 & 66.03 & 72.28 & 1.53 & 71.70 \\
\hline $\mathrm{TiO}_{2}$ & 0.51 & 0.60 & 0.51 & 0.79 & 0.79 & 0.72 & 0.28 & 0.64 \\
\hline $\mathrm{Al}_{2} \mathrm{O}_{3}$ & 14.41 & 18.66 & 15.23 & 15.16 & 11.56 & 11.79 & 14.70 & 17.78 \\
\hline $\mathrm{Fe}_{2} \mathrm{O}_{3}$ & 4.02 & 4.66 & 4.13 & 7.66 & 9.04 & 6.42 & 2.33 & 3.79 \\
\hline $\mathrm{MnO}$ & 0.05 & 0.05 & 0.05 & 0.12 & 0.14 & 0.08 & 0.05 & 0.05 \\
\hline $\mathrm{MgO}$ & 0.73 & 0.88 & 0.80 & 2.08 & 2.65 & 1.14 & 0.40 & 0.77 \\
\hline $\mathrm{CaO}$ & 0.69 & 1.05 & 0.83 & 4.36 & 6.05 & 3.25 & 2.46 & 1.20 \\
\hline $\mathrm{Na}_{2} \mathrm{O}$ & 0.80 & 0.84 & 1.00 & 1.43 & 1.70 & 1.33 & 4.04 & 0.91 \\
\hline $\mathrm{K}_{2} \mathrm{O}$ & 2.41 & 3.07 & 2.54 & 2.38 & 1.79 & 2.73 & 3.93 & 2.93 \\
\hline $\mathrm{P}_{2} \mathrm{O}_{5}$ & 0.06 & 0.06 & 0.06 & 0.12 & 0.14 & 0.12 & 0.11 & 0.06 \\
\hline $\mathrm{Ba}$ & 562 & 707 & 601 & 471 & 475 & 516 & 808 & 738 \\
\hline $\mathrm{Rb}$ & 110 & 144 & 118 & 100 & 71 & 110 & 155 & 131 \\
\hline $\mathrm{Sr}$ & 105 & 128 & 125 & 117 & 119 & 101 & 494 & 159 \\
\hline V & 63 & 79 & 67 & 167 & 220 & 148 & 24 & 78 \\
\hline Y & 27 & 27 & 28 & 29 & 27 & 24 & 17 & 32 \\
\hline
\end{tabular}

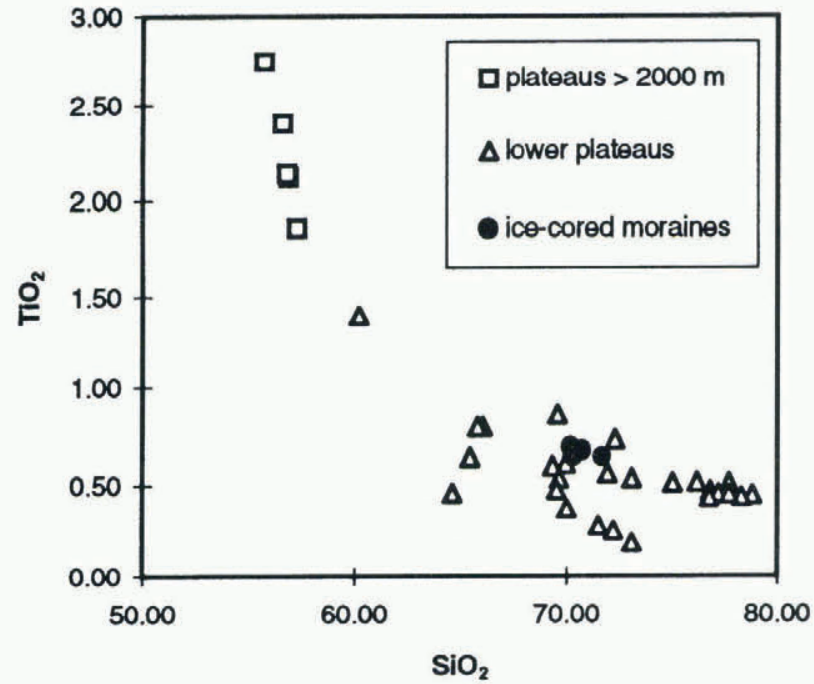

Fig. 2. Wt $\% \mathrm{TiO}_{2}$ plotted vs $w t \% \mathrm{SiO}_{2}$ of till blankets and ice-cored moraines in the Prince Albert Mountains.

distributions usually encountered in glacial sediments. The two coarsest sand fractions (up to $2 \mathrm{~mm}$ ) are extrapolated.

\section{RESULTS}

\section{Geochemistry}

Geochemical composition of the tills on the highest summit plateaus $\left(>2000\right.$ ma.s.l.) shows high values of $\mathrm{TiO}_{2}$ and $\mathrm{Fe}_{2} \mathrm{O}_{3}$, and low values of $\mathrm{SiO}_{2}$ (Table 1; Fig. 2). The tills are geochemically very similar to Kirkpatrick Basalts and have very low regional variability. $\mathrm{TiO}_{2}$ and $\mathrm{Fe}_{2} \mathrm{O}_{3}$ levels of these tills are higher than or comparable with the enriched cap rock covering the Kirkpatrick Basalt lava flows (Faure and others, 1974; Siders and Elliot, 1985). Geochemical composition of samples from lower summits and terraces (1200$1600 \mathrm{~m}$ a.s.l.) is more variable. $\mathrm{TiO}_{2}$ and $\mathrm{Fe}_{2} \mathrm{O}_{3}$ contents are lower than in tills from the highest summit plateaus (Table 2; Fig. 2). Some geochemical data show a resemblance to the geochemical analyses of Ferrar Group dolerites (Kyle, 1980). However, the tills from the lower summits and terraces are all $\mathrm{SiO}_{2}$-enriched. The samples from the ice-cored moraines have characteristically high $\mathrm{SiO}_{2}$ contents and high levels of

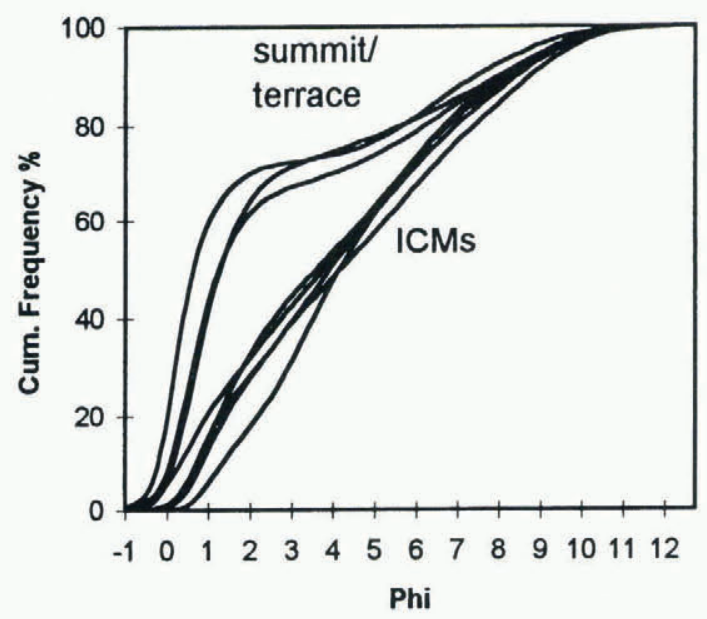

Fig. 3. Grain-size data of tills from Griffin Nunatak. Note clear separation of tills from summit and high terraces (Sirius Group) and ice-cored moraines (ICMs). 


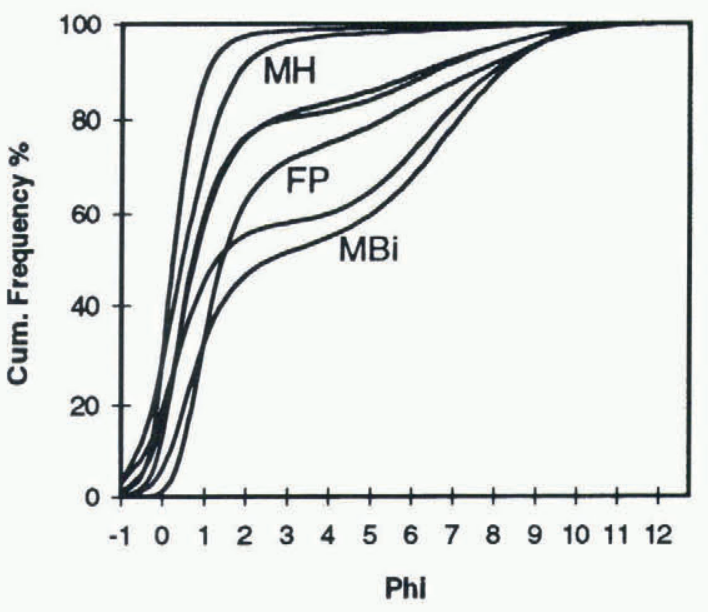

Fig. 4. Grain-size data of tills from Mount Billing, Mount Howard and Ford Peak (Sirius Group).

Ba. Hughes Bluff samples have high $\mathrm{Na}_{2} \mathrm{O}, \mathrm{K}_{2} \mathrm{O}, \mathrm{Ba}$ and $\mathrm{Sr}$ contents (Table 2).

\section{Grain-size analysis}

Although geochemically very similar, samples from the summits of Brimstone Peak $(2340 \mathrm{~m})$, Outpost Nunatak $(2170 \mathrm{~m})$ and Griffin Nunatak $(2260 \mathrm{~m})$ have variable grain-size distributions. Sandy tills from Griffin Nunatak (Fig. 3) and the western side of Brimstone Peak have high $(>25 \%)$ silt and clay contents. Samples from Outpost Nunatak and Brimstone Peak are much coarser $(<5 \%$ silt and clay). Samples from ice-cored moraines at the northeastern side of Griffin Nunatak are fine-grained $(>50 \%$ silt and clay; Fig. 3). This suggests that the tills from the summit

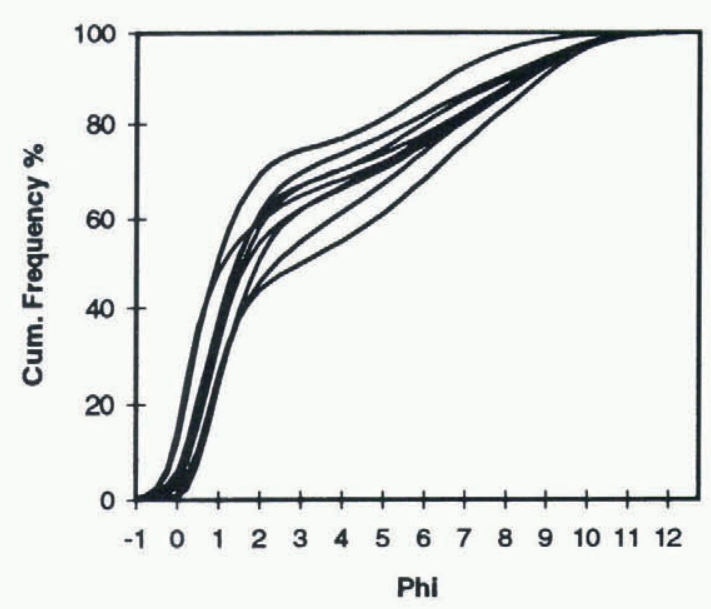

Fig. 5. Grain-size data of tills from Ricker Hills/Morris Basin (Sirius Group).

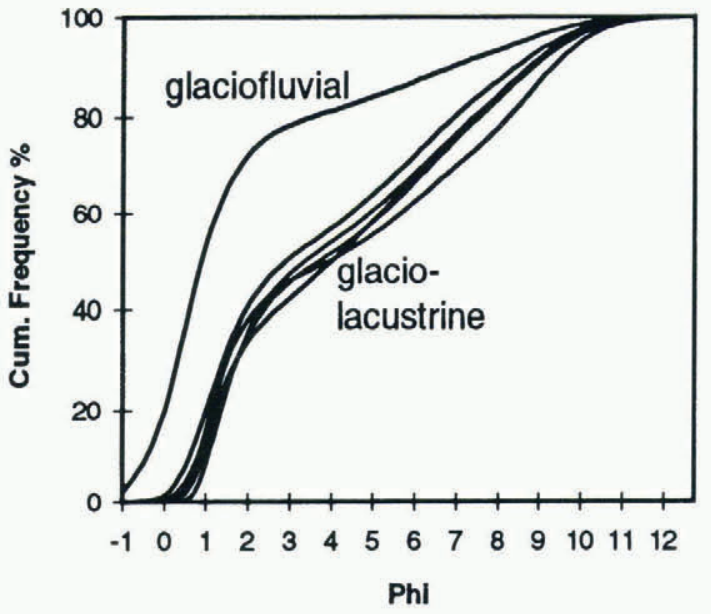

Fig. 6. Grain-size data of one glaciofluvial sample and five glaciolacustrine samples from Cirque Valley (Ricker Hills).

and high terraces of Griffin Nunatak have quite different provenance compared with the ice-cored moraines.

Bimodal silty tills occur at a high terrace $(1370 \mathrm{~m})$ and the summit $(1600 \mathrm{~m}$ ) of Mount Billing (Fig. 4), at Ford Peak $(1360 \mathrm{~m})$ and at terraces $(1300-1650 \mathrm{~m})$ at Ricker Hills (Fig. 5). Samples from Mount Howard $(1300-1450 \mathrm{~m})$ are coarser-grained, as are some of the Ricker Hills samples.

Grain-sizes of presumably glaciolacustrine deposits and a glaciofluvial deposit in valleys at $900-1000 \mathrm{~m}$ elevation in Cirque Valley (Ricker Hills) are plotted in Figure 6. The glaciolacustrine deposits contain up to $52 \%$ silt and clay, and the glaciofluvial deposit contains $80 \%$ sand. The age of the glaciolacustrine and glaciofluvial sediments is unknown. Today a small frozen lake covers the valley floor. Lake levels must have been higher, probably during the Last Glacial Maximum, since the valley is filled with lacustrine sediments up to $25 \mathrm{~m}$ above the present lake level.

\section{DISGUSSION}

\section{Stratigraphy}

We distinguish three groups of glacial deposits which we discuss below in descending order of elevation and age. A summary of results and interpretations is given in Table 3 .

(1) Geochemical composition of the tills on the high summit plateaus ( $>2000$ m a.s.l.) is very similar to Kirkpatrick Basalt whole rock geochemistry (Table 1). The Kirkpatrick Basalt sequence is locally preserved in the Transantarctic Mountains and stretches from northern Victoria Land to the Pensacola Mountains (Kyle, 1980). The presence of glacially sculptured bedrock overlain by

Table 3. Summary and interpretation of results; stratigraphy of glacigene units in the Prince Albert Mountains

\begin{tabular}{|c|c|c|c|c|c|c|}
\hline & Age & Unit & Sediment type & Texture & Geochemistry & Provenance \\
\hline $3 c$ & Late Pleistocene & David Glacier till & Till & $50-95 \%$ sand & High $\mathrm{SiO}_{2}, \mathrm{Ba}, \mathrm{Sr}$ & Granite basement \\
\hline $3 b$ & Late Pleistocene & Ice-cored moraines & Sublimation till & $<50 \%$ sand & High $\mathrm{SiO}_{2}, \mathrm{Al}_{2} \mathrm{O}_{3}, \mathrm{Ba}$ & Beacon, Ferrar, basement \\
\hline $3 \mathrm{a}$ & Late Pleistocene & Cirque Valley & Lacustrine & $48-52 \%$ sand & $\mathrm{High} \mathrm{SiO}_{2}, \mathrm{Al}_{2} \mathrm{O}_{3}, \mathrm{Ba}$ & Beacon, Ferrar, basement \\
\hline 2 & Late Pliocene & Sirius till II & Till & $54-98 \%$ sand & Higher $\mathrm{SiO}_{2}$, lower $\mathrm{Fe}_{2} \mathrm{O}_{3}$ & Beacon, Ferrar \\
\hline 1 & Pre-Pliocene & Sirius till I & Till & $67-98 \%$ sand & High $\mathrm{TiO}_{2}, \mathrm{Fe}_{2} \mathrm{O}_{3}$ & Kirkpatrick Basalts \\
\hline
\end{tabular}


a glacial diamict points to former glaciation of the Kirkpatrick Basalt plateau, which, since there is no indication of admixture of other lithologies (notably basement), occurred prior to its dissection by glacial valleys. The highly variable grain-sizes may be associated with variable crystal size of the source rock.

(2) The bimodal silty-sandy tills at Mount Billing (1370 and $1600 \mathrm{~m}$ ) have a mixed geochemical composition, of Beacon and Ferrar provenance (Tables 2 and 3). Higher levels of $\mathrm{SiO}_{2}$ are caused by the admixture of Beacon Supergroup material. The discovery of diatoms with age ranges of early and mid-Pliocene to Recent allows correlation with deposits from the Sirius Group elsewhere in the Transantarctic Mountains, assuming that the diatoms were deposited by ice. Samples from Mount Howard are much more coarse-grained, but also contain marine diatoms and are geochemically similar to the Mount Billing samples. Glaciolacustrine and glaciofluvial deposits occur at Cirque Valley (Ricker Hills). These probably date from the late Pleistocene. Meltwater must have been present during part of the summer season to produce these deposits.

The composition of the Hughes Bluff samples is completely different from that of other tills within this group. High $\mathrm{Ba}$ and $\mathrm{Sr}$ contents indicate a granitic basement provenance. David Glacier eroded a deep trench down to $1630 \mathrm{~m}$ below sea level into basement rocks (Swithinbank, 1988; Verbers and Damm, 1994). Even minor Pleistocene fluctuations of David Glacier covered Hughes Bluff, which is only $10 \mathrm{~m}$ above the present ice surface. The presence of mid-Pliocene diatoms in the deposit, and the basement provenance, suggest that during the mid-Pliocene David Glacier was a fjord from which these deposits originated. Therefore, the formation of the large outlet glacier valleys, commonly coinciding with major transverse faults, probably occurred before the Pliocene (Van der Wateren and others, 1996).

(3) Ice-cored moraines in an extensive blue-ice area at the northeastern (downwind) side of Griffin Nunatak are fine-grained ( $>50 \%$ silt and clay; Fig. 3 ). Geochemical composition suggests a mixed provenance of Beacon Supergroup, Ferrar Group and basement rocks. Enrichment in $\mathrm{SiO}_{2}$ is probably a result of reworking. The moraines, which occur up to $\sim 10 \mathrm{~m}$ above the present ice surface, were deposited by sublimation. Major blue-ice areas and associated ice-cored moraines were observed northeast of Griffin Nunatak, Ricker Hills and Brimstone Peak. Negative mass balance resulting from low accumulation rates and high ablation (sublimation) rates at the lee side of nunataks are compensated by upward ice flow (Orheim and Lucchitta, 1990). At Griffin Nunatak and Ricker Hills (Morris Basin) this produced ice flow in directions opposite to the regional trend. This process forces material from the basal transport zone up into a highlevel transport zone, and therefore material sampled from the ice-cored moraines at Griffin Nunatak (Fig. 3) represents late-Pleistocene basal till.

\section{Glacial history}

The presence of glacial erosion features and till blankets on the highest plateaus suggests that they were covered by temperate ice, i.e. ice sliding over bedrock under conditions of basal melting. To produce these conditions requires either large ice thicknesses producing basal ice at the pressuremelting point, or small ice caps under conditions warmer than today. The direction of the streamlined bedrock features (southwest-northeast) favors continental glaciation, but does not exclude a model with local glaciers. No marine diatoms were found in the deposits associated with this glacial phase, suggesting that this glaciation predated the early-mid-Pliocene deglaciation phase inferred from the diatoms in the Sirius Group sediments.

Burckle and others (1997) propose an alternative mechanism for the emplacement of marine diatoms in glacigene sediments: eolian transport onto the ice sheet, followed by glacial transport to the base of the ice sheet or the ice-sheet margin. According to their model, for diatoms blown onto the ice sheet $1800 \mathrm{~km}$ from the ice margin, the time required for them to reach the bed or be deposited is up to $380 \mathrm{ka}$. This mechanism produces age constraints for the Sirius Group similar to those produced by Webb and Harwood's (1993) deglaciation hypothesis. Therefore, we assume that the late-Pliocene age of the Sirius Group is correct and that glaciation of the highest plateaus predated the early-Pliocene age of the diatoms in the Sirius Group.

The regional southwest-northeast-trending striation patterns on the lower plateaus and high terraces point to EAIS advance across an area more than ten times wider than the present David Glacier. Their present high elevation is probably due to a combination of tectonic uplift and isostatic response to valley downcutting (Van der Wateren and others, 1996).

Our model of the landscape evolution of the Prince Albert block is supported by analyses of in situ cosmogenic nuclides ${ }^{10} \mathrm{Be},{ }^{26} \mathrm{Al}$ and ${ }^{21} \mathrm{Ne}$ (Van der Wateren and others, 1996, 1997). A. L. L. M. Verbers and F. M. van der Wateren collected quartz samples for ${ }^{10} \mathrm{Be}$ and ${ }^{26} \mathrm{Al}$ surface-exposure dating from summit plateaus, erosion terraces and lateral moraines. As elsewhere in central and northern Victoria Land, exposure ages generally increase with elevation (Van der Wateren and others, 1996), suggesting that ice-surface lowering gradually exposed the topography. Yet, since in the Prince Albert block it can be demonstrated that valley erosion postdates deglaciation of the summit plateaus, we believe that thinning of the EAIS since the Miocene, as suggested by Denton and others (1991), was not the main cause of the observed exposure-age pattern in this region.

Measurements of cosmogenic ${ }^{10} \mathrm{Be},{ }^{26} \mathrm{Al}$ and ${ }^{21} \mathrm{Ne}$ are in agreement with a late-Pliocene depositional age of Sirius Group deposits on the lower summits and high terraces (Van der Wateren and others, 1996, 1997). The summit of Ricker Hills $(1650 \mathrm{~m})$ produced ${ }^{10} \mathrm{Be}$ minimum exposure ages of 1.26 and $0.89 \mathrm{Ma}$. We modeled ${ }^{10} \mathrm{Be}$ concentrations for a number of samples from summit plateaus and erosion terraces undergoing different uplift rates. Surface uplift rates of $0.5-1 \mathrm{~km} \mathrm{Ma}^{-1}$ produced exposure ages which are in good agreement with a late-Pliocene age of the supposedly Sirius Group tills. Including ${ }^{26} \mathrm{Al}$ in our model calculations produces $0.66 \mathrm{~km} \mathrm{Ma}^{-1}$ since $2.5 \mathrm{Ma}$ as the most likely uplift rate for the measured ${ }^{10} \mathrm{Be}$ and ${ }^{26} \mathrm{Al}$ concentrations, including $\sim 300 \mathrm{ka}$ of burial of the surface by ice during this period. Pliocene/Pleistocene surface uplift becomes even more likely considering that downcutting of more than $90 \%$ of the original summit erosion surface to an average $\sim 1000 \mathrm{~m}$ lower level would produce $500-600 \mathrm{~m}$ of erosional rebound. 
Ice-cored moraines at the lee sides of large nunataks indicate cold climate conditions in the area, since the formation of the moraines, and the intact sediment cover of sublimation till, points to the absence of meltwater during this time. The moraines are probably late Pleistocene, which is confirmed by a ${ }^{10} \mathrm{Be}$ exposure age of $29 \pm 4 \mathrm{ka}$ from an icecored moraine at Morris Basin.

Van der Wateren and Verbers (1994) proposed that the present landscape of the area is the result of at least three distinct glacial episodes. The summit plateaus up to $2340 \mathrm{~m}$ represent the original roughly planar surface, which was later dissected by downcutting of valley glaciers along fault-lines in the late Pliocene to form the highest level of terraces, where the diatom-bearing Sirius Group tills were deposited. Grain-size and geochemical data of the sediments, biostratigraphy and surface-exposure ages confirm this model. The terraces are interpreted as the floors of former valleys. A similar association of high glaciated platforms and diatom-bearing Sirius Group sediments in highelevation valleys is found in the Shackleton, Reedy and Beardmore Glacier areas (Mercer, 1968, 1972; Mayewski and Goldthwait, 1985; McKelvey and others, 1991).

Mercer (1972) originally defined the Sirius Formation as compact drift that unconformably overlies pre-Tertiary rocks on Mount Sirius in the Beardmore Glacier area. According to this definition, both pre-Pliocene plateau tills and Pliocene tills on lower summits and terraces belong to what was later called the Sirius Group (McKelvey and others, 1991). It is possible that major trunk valleys already existed when the highest plateaus in the Prince Albert Mountains were glaciated and that this involves an episode of alpine glaciation. The plateaus were later dissected, and the diatom-bearing Sirius tills were deposited on terraces cut in these plateaus. The current debate considering the age of the Sirius Group developed as a result of interpretations of both these pre-Pliocene tills and the diatom-bearing strata. The result is that some, considering glacial deposits at high mountain summits, interpret the Sirius Group as a thin sequence of pre-Pliocene glacial deposits, whereas others, considering diatom-bearing deposits in valleys and on terraces, date the Sirius Group as mainly Pliocene. However, McKelvey and others (1991) suggested that the Sirius Group may include deposits of "significantly different ages".

\section{GONCLUSIONS}

The results of our till-provenance study are in agreement with at least three major glacial episodes in the southern Prince Albert Mountains. Glacial erosion and deposition of a till blanket suggest temperate glacial conditions for a glacial period preceding dissection of the landscape. Fjord conditions in David Glacier valley during the early-midPliocene are evidence of a major deglaciation phase during that period. Granitic basement tills, morainic ridges and ice-cored moraines are evidence of a higher Pleistocene ice surface. We propose the following model for the paleoclimatic history of the southern Prince Albert Mountains:

(1) Pre-Pliocene glaciation of the Kirkpatrick Basalt plateau; this implies glaciation of the Kirkpatrick Basalt by temperate ice without erosion of pre-Jurassic rocks. This episode represents the first phase of Sirius Group deposition.
(2) Deglaciation and marine transgression in the David Glacier trench.

(3) EAIS readvance and dissection of the landscape followed by deposition of diatom-bearing Sirius Group tills later than mid-Pliocene.

(4) Partial deglaciation and cirque glaciation of the nunataks (Verbers and Damm, 1994). Glaciolacustrine and glaciofluvial deposits are evidence of the presence of meltwater at the end of this glacial phase.

(5) Pleistocene glaciations. Morainic ridges near the present ice surface, ice-cored moraines and granitic tills are remnants of this phase. Composition of the tills indicates further dissection of the landscape down into basement.

The stratigraphy and geomorphology of the southern Prince Albert Mountains are very similar to those found in areas south of the Dry Valleys. We believe that the presence of clasts with Pliocene marine diatoms in the Sirius Group requires emplacement by a late-Pliocene temperate continental ice sheet, but some of the diatoms in surface units of thin till blankets may be transported in a different way. In the southern Prince Albert Mountains the diatom ages are confirmed by minimum surface exposure ages. A problem is that thick sequences of diatom-bearing Sirius Group tills are absent in the Dry Valleys. This paper does not solve this problem, but it contributes to our understanding of the terrestrial Cenozoic glacial record, showing that the Dry Valleys form a break in an otherwise continuous sequence of temperate Neogene glacial deposits.

Correlation of the terrestrial glacial geologic record and the record from the Ross Sea basin may be useful in reconstructing glacial dynamics and tectonic processes. In addition, the sedimentology of the Sirius Group has never been described in detail, and correlations have been based on diatoms alone. The Sirius Group comprises a variety of deposits: lodgement tills, glaciolacustrine, glaciofluvial and marine deposits. A detailed sedimentological, mineralogical and geochemical analysis of the Sirius Group from several areas in the Transantarctic Mountains will provide a better basis for correlations and, if the biostratigraphy is correct, may provide information about the nature of Neogene climate in Antarctica.

\section{REFERENCES}

Barrett, P.J., C.J. Adams, W. C. McIntosh, C. C. Swisher, III and G. S. Wilson. 1992. Geochronological evidence supporting Antarctic deglaciation three million years ago. Nature, 359(6398), 816-818.

Burckle, L. H., D. E. Kellogg, T. B. Kellogg and J. L. Fastook. 1997. A mechanism for emplacement and concentration of diatoms in glacigenic deposits. Boreas, 26, $55-60$.

Crowley, T.J. 1996. Pliocene climates: the nature of the problem. Mar. MicroPalaeontol., 27(1-4), 3-12.

Denton, G. H., M. L. Prentice and L. H. Burckle. 1991. Cainozoic history of the Antarctic ice sheet. In Tingey, R.J., ed. The geology of Antarctica. Oxford, Clarendon Press, 365-433. (Oxford Monographs on Geology and Geophysics 17.)

Faure, G., J. R. Bowman, D. H. Elliot and L. M. Jones. 1974. Strontium isotope composition and petrogenesis of the Kirkpatrick basalt, Queen Alexandra Range, Antarctica. Contrib. Mineral. Petrol., 48, 153-169.

Haq, B. U., J. Hardenbol and P. R. Vail. 1987. The chronology of fluctuating sea levels since the Triassic. Science, 235, 1156-1167.

Harwood, D. M. and T. Maruyama. 1992. Middle Eocene to Pleistocene diatom biostratigraphy of Southern Ocean sediments from the Kerguelen Plateau, Leg 120. In Wise, S.W. and R. Schlich, eds. Ocean Drilling Program. Proceedings. Scientific Results. Vol. 120. College Station, TX, Ocean Drilling Program, 683-734. 
Kyle, P. R. 1980. Development of heterogeneities in the subcontinental mantle: evidence from the Ferrar Group, Antarctica. Contrib. Mineral. Petrol., 73, 89-104.

Marchant, D. R., G. H. Denton, D. E. Sugden and C. C. Swisher, III. 1993a. Miocene glacial stratigraphy and landscape evolution of the western Asgard Range, Antarctica. Geogr. Ann., 75A(4), 303-330.

Marchant, D. R., G. H. Denton and C. S. Swisher, III. 1993b. MiocenePliocene-Pleistocene glacial history of Arena Valley, Quartermain Mountains, Antarctica. Geogr. Ann., 75A(4), 269-302.

Mayewski, P. A. and R. P. Goldthwait. 1985. Glacial events in the Transantarctic Mountains: a record of East Antarctic ice sheet. In Turner, M. D. and J. E. Splettstoesser, eds. Geology of the Transantarctic Mountains. Washington, DC, American Geophysical Union, 275-324. (Antarctic Research Series 36.)

McKelvey, B. C., P. N. Webb, D. M. Harwood and M. C. G. Mabin. 1991. The Dominion Range Sirius Group: a record of the Late PlioceneEarly Pleistocene Beardmore Glacier. In Thomson, M. R. A., J. A. Crame and J.W. Thomson, eds. Geological evolution of Antarctica. Cambridge, Cambridge University Press, 675-682.

Mercer, J. H. 1968. Glacial geology of the Reedy Glacier area, Antarctica. Geol. Soc. Am. Bull., 79(4), 471-486.

Mercer, J. H. 1972. Some observations on the glacial geology of the Beardmore Glacier area. In Adie, R.J., ed. Antarctic geology and geophysics. Oslo, Universitetsforlaget, 427-433. (International Union of Geological Sciences, Ser. B, No. 1.)

Orheim, O. and B. Lucchitta. 1990. Investigating climate change by digital analysis of blue ice extent on satellite images of Antarctica. Ann. Glaciol, 14, $211-215$.

Raymo, M. E. 1992. Global climate change: a three million year perspective. In Kukla, G. J. and E. Went, eds. Start of a glacial. Berlin, etc., SpringerVerlag, 207-223. (NATO ASI Series I: Global Environmental Change 3.)

Shackleton, N. J., M. A. Hall and D. Pate. 1995. Pliocene stable isotope stratigraphy of site 846. In Mayer, N. G., L. A. Janecek, T. R. Palmer-Julson and T. H. van Andel, eds. Ocean Drilling Program. Proceedings. Scientific Results. Vol. 138. College Station, TX, Ocean Drilling Program, 337-355.

Siders, M. A. and D. H. Elliot. 1985. Major and trace element geochemistry of the Kirkpatrick Basalt, Mesa Range, Antarctica. Earth Planet. Sci. Lett., 72, 54-64.

Sugden, D. E., D. R. Marchant and G. H. Denton. 1993. The case for a stable
East Antarctic ice sheet: the background. Geogr. Ann., 75A (4), 151-154 Swithinbank, C. 1988. Antarctica. U.S. Geol. Surv. Prof. Pap. 1386-B, B1-B138. Van der Wateren, F. M. and A. L. L. M. Verbers. 1994. Differential tectonic uplift of fault blocks in the West Antarctic rift system and their landscape evolution histories. In Van der Wateren, F. M., A. L. L. M. Verbers and F. Tessensohn, eds. Landscape evolution in the Ross Sea area, Antarctica. Haarlem, The Netherlands, RGD, 125-128.

Van der Wateren, F. M. and 11 others. 1996. Glaciation and deglaciation of the uplifted margins of the Cenozoic West Antarctic rift system, Ross Sea, Antarctica. Geol. Jahrb., Ser. B, 89, 123-155.

Van der Wateren, F. M., T. Dunai and W. Klas. 1997. Evidence of differential neotectonic and glacial histories of regions within the Transantarctic Mountains, based on measurements of in situ osmogenic nuclides ${ }^{3} \mathrm{He},{ }^{10} \mathrm{Be},{ }^{21} \mathrm{Ne}$ and ${ }^{26} \mathrm{Al}$. [Abstract.] Terra Nova, 9, EUG Abstracts Volume, 219.

Verbers, A. L. L. M. and V. Damm. 1994. Morphology and late Cenozoic $(<5 \mathrm{Ma})$ glacial history of the area between David and Mawson Glaciers, Victoria Land, Antarctica. Ann. Glaciol., 20, 55-60.

Verbers, A. L. L. M. and F. M. van der Wateren. 1992. A glacio-geological reconnaissance of the southern Prince Albert Mountains, Victoria Land, Antarctica. In Yoshida, Y., K. Kaminuma and K. Shiraishi, eds. Recent progress in Antarctic earth sciences. Tokyo, Terra Scientific Publishing Co., 715-719.

Vermeulen, F. J. M. 1994. Till provenance in North Victoria Land: a pilot study based on geochemistry. In Van der Wateren, F. M., A. L. L. M. Verbers and F. Tessensohn, eds. Landscape evolution in the Ross Sea area, Antartica. Haarlem, The Netherlands, RGD, 125-128.

Webb, P.-N. and D. M. Harwood. 1993. Pliocene fossil Nothofagus (southern beech) from Antarctica: phytogeography, dispersal strategies and survival in high latitude glacial-deglacial environments. In Alden, J., J. L. Mastrantonio and S. Ødum, eds. Forest development in cold climates. New York and London, Plenum Press, 135-165. (NATO ASI Series A: Life Sciences 244.)

Webb, P. N., D. M. Harwood, B. C. McKelvey, J. H. Mercer and L. D. Stott. 1984. Cenozoic marine sedimentation and ice-volume variation on the East Antarctic craton. Geology, 12(5), 287-291.

Wörner, G. 1992. Kirkpatrick lavas, Exposure Hill Formation and Ferrar Sills in the Prince Albert Mountains, Victoria Land, Antarctica. Polarforschung, $\mathbf{6 0}(2), 1990,87-90$. 